\title{
Challenges of Iot/5g Advancement in the Oil Palm Upstream
}

\author{
Veena Shashikant ${ }^{1 *}$, Abdul Rashid M. Shariff ${ }^{1,2,3^{*}}$, Lee Y. Ping ${ }^{4}$, Aimrun Wayayok ${ }^{1,2,3}$ \\ \& Kamal M. Rowshon ${ }^{1}$
}

${ }^{1}$ Department of Biological and Agricultural Engineering, Faculty of Engineering, Universiti Putra Malaysia, 43400 Serdang, Selangor, Malaysia

${ }^{2}$ Laboratory of Plantation System Technology and Mechanization, Institute of Plantation Studies, Universiti Putra Malaysia, 43400 Serdang, Selangor, Malaysia.

${ }^{3}$ Smart Farming Technology Research Center (SFTRC), Universiti Putra Malaysia, 43400 Serdang, Malaysia.

${ }^{4}$ FGV R\&D Sdn Bhd, Level 9, Wisma FGV, Jalan Raja Laut, 50350 Kuala Lumpur, Malaysia.

*Corresponding author E-mail: rashidpls@upm.edu.my; vnajogi@gmail.com

Received 13 July 2019; Accepted 22 August 2021; Available online 28 October 2021

\begin{abstract}
G technology is vital for the development of Internet of Things (IoT) application in Malaysia to enhance the development of the agriculture and plantation industry. The nation is marching towards big data and artificial intelligence. Consequently, having $5 \mathrm{G}$ networks merging with IoT technology as a platform would contribute to the country's gross domestic income up to RM 12.7 billion ringgit. There are tangible and intangible benefits to the oil palm industry if the technologies of 5G/IOT are implemented. In the oil palm industry, the technology of 5G network can uplift the current technology in the field to enhance the labour productivity. On the other hand, the dependency on foreign workers can also be reduced. Apart from that, the use of 5G/IoT will improve crop productivity and land use efficiency to improve palm oil yield. However, IoT platforms relying on 5G technology will be challenging in rural oil palm areas where there is low signal for communication. In relation to that, preliminary research shows that LoRA technology that is similar to $5 \mathrm{G}$ technology is able to work in remote areas. $5 \mathrm{G} / \mathrm{IoT}$ related technology implementation is vital in the oil palm plantation at the upstream level.
\end{abstract}

Keywords: Oil palm technology, Economic influence, Labour management, 5G/IoT.

\section{Introduction}

The term 5G may strike global interest to all technocrats.5G stands for Fifth generation wireless technology in digital cellular networks. 5G is believed to provide high data rates, low latency, seamless coverage, low in power usage and highly reliable communication. Today's 2G/3G/4G mobile networks primarily use frequencies in the range of $700 \mathrm{MHz}$ to $42 \mathrm{GHz}$ globally. In this region, the Malaysian Communication and Multimedia Commission (MCMC) has allocated spectrum bands of $700 \mathrm{MHz}$, 3.5 GHz and $26 / 28 \mathrm{GHz}$ for $5 \mathrm{G}$ technology as its initial development (MCMC Press Release, 2020). As cited by the Malaysian Institute of 
Economic Research, 5G related economic activities are stimulated to contribute an additional of RM 12.7 billion to the gross domestic product in the year of 2021 to 2025 (The Edge Markets, 2020).

In the direction of moving towards 5G, agriculture is part of the other verticals chosen by the MCMC. It is undertaken in the year 2020 along with industry partners and ministries especially the Ministry of Agriculture and Agro-based industry (MOA) (Malay Mail, 2020). In a 5G network, devices will be connected to the mobile network wirelessly that enable billions of smart devices to be autonomously interconnected while ensuring security and privacy. 5G networks will allow services including remote monitoring and real time control of smart devices, which will support machine and Internet of Things (IoT). This paper intends to discuss the scope of the upstream processes that is related to the activities in the oil palm field mainly associated to the potential economic benefit, challenges in the field and technological constrains faced by implementing 5G/IoT.

\section{Economic Benefits of 5G/IOT in Upstream Oil Palm Plantation}

In the oil palm industry, keeping a low cost for the plantation per hectare is the main goal of every plantation manager. The cost at the plantation is mainly due to weeding, fertilizer application, harvesting, and transportation of FFB, land clearance and replanting and other costs that incur. The availability of 5G/IOT technology is able to reduce the operational cost even further and benefit the oil palm plantation as a whole. Table (1) summarizes the benefits of 5G/IOT technology in the plantation at the upstream level. In the context of land clearance and replanting, it is important in using remote sensing as a tool to aid in planning the position of the oil palm trees. This is especially to help in decision making and economically determine the optimal number of palms trees especially in the peatland or hilly terrace areas (Rudiyanto et al., 2018). In the lining task which usually starts after the land preparation phase, the most important part is the position of the seedlings to be planted. It is believed that an evenly spaced of palms tree will ensure that each palm tree has the same access to nutrients, water and sunlight and to achieve optimum stand per hectare.

Conventionally, palm oil plantation has a lining team that needs of about 6 people per day that has been trained and equipped. The multi-GNSS technology is capable to reduce the productivity time with high accuracy of less than $1 \mathrm{~m}$ in a precise positioning system (Aini et al., 2014). Reduction of labour is estimated to be 2 man per day which will bring significant economic benefit to the plantation as illustrated in Table 1. In addition, the open source goGPS 1.0 version software (Antonio et al.,2016) with Google/HTC Nexus 9 tablet gives better position precision with an accuracy of $10 \mathrm{~cm}$ (Realini et al., 2017). The mentioned goGPS software was validated in the field and found to be the initial development to open new perspectives using of the shelf market devices for precise positioning and professional surveying purposes in future. However, an u-blox EVK$6 \mathrm{~T}$ receiver with its standard ANN-MS patch antenna is needed to be coupled with the Google/HTC Nexus 9 to allow a precise position (Realini et al., 2012, 2017). During the harvesting and FFB collection, counting of the harvested fruit bunches are done manually by plantation supervisors. 
Shashikant et al. / Basrah J. Agric. Sci., 34(Special Issue 1): 190-198, 2021

Table (1): Tangible and intangible economic benefits to the oil palm at upstream level activities when using IoT/5G technology.

\begin{tabular}{|c|c|c|c|c|}
\hline Activities & $\begin{array}{l}\text { Tangible benefit } \\
\text { per } 1000 \mathrm{Ha}^{*}\end{array}$ & Intangible benefit & $\begin{array}{c}\text { Cost per } \\
1000 \mathrm{Ha} \\
\text { Cost }^{*}\end{array}$ & Reference \\
\hline $\begin{array}{l}\text { Land clearance } \\
\text { and preparation }\end{array}$ & - & $\begin{array}{l}\text { Organized positioning of } \\
\text { palm trees to maximize } \\
\text { planting area especially on } \\
\text { hilly or terrace fields. }\end{array}$ & $\begin{array}{c}\text { USD } 14.39 \\
-23.98\end{array}$ & $\begin{array}{r}\text { Rudiyanto et al., } \\
2018\end{array}$ \\
\hline Planting-lining & $\begin{array}{l}\text { USD } 479.62 \\
\text { Increase productivity } \\
\text { by reducing } 2 \text { man } \\
\text { per day }\end{array}$ & - & USD 799.36 & Aini et al., 2014 \\
\hline Planting-lining & - & $\begin{array}{l}\text { precise position with } \\
\text { accuracy of } 10 \mathrm{~cm} .\end{array}$ & $\begin{array}{c}\text { Cost of } \\
\text { Google/HT } \\
\text { C Nexus } 9 \\
\text { tablet with } \\
\text { standard } \\
\text { ANN-MS } \\
\text { patch } \\
\text { antenna. }\end{array}$ & $\begin{array}{r}\text { Realini et al., } \\
2017\end{array}$ \\
\hline $\begin{array}{l}\text { Harvesting and } \\
\text { FFB Collection }\end{array}$ & - & $\begin{array}{l}\text { Data of harvesters' FFB } \\
\text { collection is uploaded to } \\
\text { computer at estate's office } \\
\text { for payment with accurate } \\
\text { number of bunches recorded } \\
\text { and GPS location. }\end{array}$ & $\begin{array}{l}\text { Cost of an } \\
\text { IoT - } \\
\text { compatible } \\
\text { device. }\end{array}$ & Chyan, 2018 \\
\hline $\begin{array}{l}\text { Spraying } \\
\text { Pesticide or } \\
\text { Fertilizer }\end{array}$ & $\begin{array}{l}\text { UAV spraying is five } \\
\text { times faster than } \\
\text { conventional tractor } \\
\text { and machinery } \\
\text { equipment. }\end{array}$ & - & $\begin{array}{l}\text { Cost of } \\
\text { drone and } \\
\text { maintenance } \\
\text { in long term } \\
\text { investment. }\end{array}$ & $\begin{array}{r}\text { Ramin } \\
\text { Shamshiri et al., } \\
2019\end{array}$ \\
\hline $\begin{array}{l}\text { Managing } \\
\text { fertilizer } \\
\text { allocation and } \\
\text { estimates }\end{array}$ & 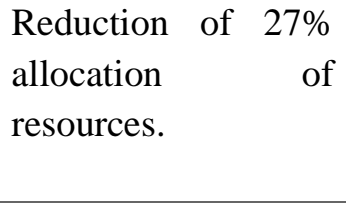 & $\begin{array}{l}\text { Accurate counting and } \\
\text { location of current oil palm } \\
\text { stand with reduction of } \\
\text { estimation error. }\end{array}$ & $\begin{array}{l}\text { Cost of } \\
\text { drone and } \\
\text { camera } \\
\text { mounted. }\end{array}$ & $\begin{array}{r}\text { Kalantar et al., } \\
2017\end{array}$ \\
\hline
\end{tabular}

*Note: 1 USD $=4.17$ RM (Rate on $25^{\text {th }}$ August 2020). Rate in USD is estimated according to current market value.

A potential software using IoT-compatible device has been developed to count the harvested fruit (Chyan, 2018). The software, which is at its preliminary stage, can be installed to an IoT-compatible device to count the quantity of fruit bunches harvested by harvester and the GPS location. An audio based machine learning algorithm to record the number of fruit bunches to be harvested are currently carried out manually by the plantation supervisors. In this initial research, the machine learning algorithm mainly uses multilayer neural network classifier that was done on Windows 10 Notebook. With the ability of connecting to wireless network, the mentioned work can be explored to provide real time information. In the latest trend of using drone to map the oil palm trees, the benefit of the IoT technology will allow the plantation to provide data with extra precision 
by allowing them to either save cost, increase yield, or speed up productivity (Innovation, News Straits Times, 2018). Spraying of pesticide during an outbreak using Unmanned Aerial Vehicle (UAV) can be targeted to the area with the accounted severity of damage. UAV equipped with distance-measuring and light detection sensors. The mentioned sensors then can scan the ground and adjust the flight altitude with the varying topography of the plantation. Thus, the precise amount of spraying pesticide solutions can be applied evenly across the crop canopy. It is estimated that UAV spraying is five times faster than conventional tractor and machinery equipment (Ramin et al., 2019).

Mentioned practice will observed in an increased efficiency for canopy spraying while reducing wastage of sprayed chemical into penetrating non target area example like the soil. An added benefit of using artificial intelligence application, the images gathered from the drones can be processed to count the missing trees. Kattenborn et al. (2014) showed mapping accuracy of $86.1 \%$ for the entire study area and $98.2 \%$ for dense growing palm stands using photogrammetric point clouds data captured using UAV. On the other hand, a localized study in Melaka, Malaysia by Kalantar et al. (2017), showed similar overall accuracy at $87 \%$ using object-based analysis with template matching concept in oil palm tree counting. Kelantar et al. (2017) approach using Canon S100 mounted on a fixed-wing UAV was significantly successful in minimizing errors of automated missing tree calculation about 208 palms or $27 \%$ in the study site. Mentioned study will be beneficial to the plantation management to make the fertilizer allocation and eventually lead a precise yield estimation (Kalantar et al., 2017).

\section{Labour management through technology advancement}

Labour productivity in oil palm plantation is crucial and is dependent on the specific job categories position namely: general supervisor; harvesting supervisor; harvester and fresh fruit bunch (FFB) collector; field worker; and other field workers (Abdullah et al., 2011). Among all the positions above the higher number of employments of labour are the harvester and FFB collectors due to the capacity of the physical effort in performing the activities (Ahmad et al., 2017). Commonly, these labour-intensive job positions in Malaysian oil palm industry are held up by foreign workers coming from largely from Indonesia Bangladesh, India and etc. A study conducted in the year 2010 found that out of 505,972 workers in Malaysia, $75 \%$ or 386,913 are foreigners (Ismail, 2013).

Over dependence on the foreign workers can pose a risk to the security and stability of the oil palm industry. In understanding the labour challenges faced by the country and the availability of labour in Malaysian oil palm industry, it is important to utilize technology advancement to alleviate the dependencies of labour especially from foreign workers. Occurrence of technology advancement in oil palm industry such as mechanisation of the harvesting and FFB collection at a low cost will truly be a game changer in the industry. It cuts the dependencies on foreign labour and operational costs, including foreign exchange losses where a significant portion of wage is expelled out of the country (The Edge Markets, 2018).

It is known that mechanisation or automation in plantation operations will not totally replace the field plantation work. In the aspect of harvester dependencies, there are development in the harvester's tools such as 
from traditional harvesters' pole to transformation of motorised cutter. It is known as Cantas that was introduced first in 2007 methods for an intermediate palm height of less than $5 \mathrm{~m}$ (Jelani et al., 2008a). Cantas was then patented in year 2014 (International Patent No: WO201477672A1, 2014). The recent improved version of Cantas reduces the vibration effects on the hand-arm that have recently been developed and studied by Jelani et al. (2019). For the immature palms in field, Ckat, a mechanical chisel that has the same head and engine as Cantas, but with a chisel instead of sickle for cutting can be deployed (Jelani et al., 2008b).

It is mentioned to increase harvesting productivity about 160 FFB per hour compared to about 110 FFB per hour in manual harvesting (Abd Rahim et al., 2011). The increase in harvesting efficiency by 50 FFB per hour can substantially increase labour productivity. The mentioned harvesting tools can potentially be advanced further with a sensor at the base linking a $5 \mathrm{G}$ network to allow monitoring bunch counting in real time. The capability of $5 \mathrm{G}$ network data transmission speed is able to store real time data of bunches harvested for the day in the cloud. This real-time bunch data recording could reduce the paperwork related to bunch recording in field and miscalculations in field by the harvesting supervisor. Additionally, with storing database capabilities in IoT technology, bunch ripeness and positioning of real time navigation will allow the workers to reduce their time searching in field for such bunches. For taller oil palms, mechanical harvesting machine is the latest machinery available in the oil palm industry.

There are two types of machines: based of wheel type or track based. Both the machines have hydraulic cylinders-powered arms that can be elevated up from ground for harvesting tall palms. The arm will have a cutter blade and fruit catching mechanism (Shuib et al., 2004). During harvesting, the operator manoeuvres the vehicle remotely along the harvesting path using of a joystick. An added advantage of the wheel type is that the modular design allows for flexible machine application, easy replacement, and maintenance. The 5G network can potentially be applied in harvesting machine production processes and its data can be recorded in terms of location, time, and quantity.

There is a great potential of combining IoT and $5 \mathrm{G}$ into this area where it will ultimately be an essential technology in driving the palm oil upstream. Alternatively, another motivating perspective for $5 \mathrm{G} / \mathrm{IoT}$ expansion is at the FFB collection stage. Currently, Otowey, the latest FFB transporter vehicle with electronic weighing system, has the capability to reduce three to two number of workers especially for the task of yield recording (Abd Rahim et al., 2011). Otewey transporter currently weighs bunches in the field automatically as bunches are loaded (Shuib et al., 2008). Currently, only the Otewey driver will be able to know the FFB loaded weight. Sensors supporting the 5G/IoT technology can potentially provide real-time data to the estate mill/office for the incoming bunches for the estate.

$5 \mathrm{G}$ network enhancement is expected to potentially influence the Internet of Things (IoT) technology. It is noted that most of the IoT applications, such as remote monitoring requires of medium of transmission network speed. $5 \mathrm{G}$ networks record high transmission rates of up to 10 gigabytes per seconds download speeds or 1 milliseconds latency rate (Morgan, 2019). It is expected that IoT technology will exploit and largely depend on the evolution of $5 \mathrm{G}$ network. 


\section{Shashikant et al. / Basrah J. Agric. Sci., 34(Special Issue 1): 190-198, 2021}

\section{Technology development for IoT/5G challenges}

In growing towards $5 \mathrm{G}$ network for the nation, which it is also known as the future platform for IoT technology, this platform uses the resources of radio transmission as the main framework. As it is important to grasp the $5 \mathrm{G} / \mathrm{IoT}$-compatible devices, it is expected that the level of interference between devices or sensors will also increase. It is noted as in fig. (1) that the ability of $5 \mathrm{G}$ network is able to bypass the network connection to allow for larger connectivity between base stations to exchange connection directly (Bohlsen, 2018). Malaysia, as one of the world largest palm oil producers has invested money and research resources mainly to manage and increase the oil palm productivity and yield (National Economic Advisory Council 2010; Malaysian Business Online, 2017). By adapting and embracing the current technology, researchers at present shift the focus to embrace the IoT era with big data and artificial intelligence in the oil palm application (Edge Markets, 2020).

A research conducted by Ministry of Science, Technology, and Innovation (2015), found that the IoT technology was successful to monitor pollination status of their palm trees and triggers the system once they are ready for pollination. The conventional method that was practiced in fields is by manual checking by the workers (MIMOS BERHARD, 2015). The practice is time consuming and in some cases the pollination window time frame will be missed. IoT technology has allowed plantation managers to remotely check the pollination status and planned actions needed to be implemented. In the IoT technology, fieldbased sensor networks, which are then replicated through routers and wireless gateways, depend on telecommunications networks to allow data to be updated to a cloud-based database.

An added challenge to support the IoT technology and 5G network in the remote plantation area is the lack of telecommunications network. This is especially of the oil palm plantations in the rural areas that are far from the coverage of telecommunication operator services. In some densely populated areas in the town, the connected cell phones based on telecommunication operators' networks are at the 6:1 ratio compared to rural area usage (My Convergence, 2009). However, remote areas of palm plantations in Malaysia have no services from telecommunication operators. Also, the oil palm crop structure that has a dense canopy makes it difficult for the signal to penetrate through the field. In relation to the lack of telecommunication of networks, the LoRA, that is a Long Range is a narrowband communication technology has the potential to connect devices that have large coverage distances can be an alternative (ELE Times Bureau, 2019).

The effectiveness of this LoRA technology is reported to be appropriate for remote areas. Capabilities of it include: long range of sight (from 5 to $10 \mathrm{~km}$ ); and low bitrate to allow data communication at relatively low speed and power usage. A study in an Indonesian oil palm plantation where devices such as Android based smartphone can act as a bridge between a device and the user. Smartphones are chosen to support advanced features and APIs such as mapping and processing of data (Adiono et al., 2018).

The 5G/IoT technology application in palm plantation is has immense capabilities of the 5G network that can help to unlock the enormous potential of technological enhancement for oil palm industry. Coincidently, 5G network is becoming the 
catalyst for next-generation IoT services where there is wireless access, automated network application management and support for cloud-optimized distributed network applications (Morgan, 2019).

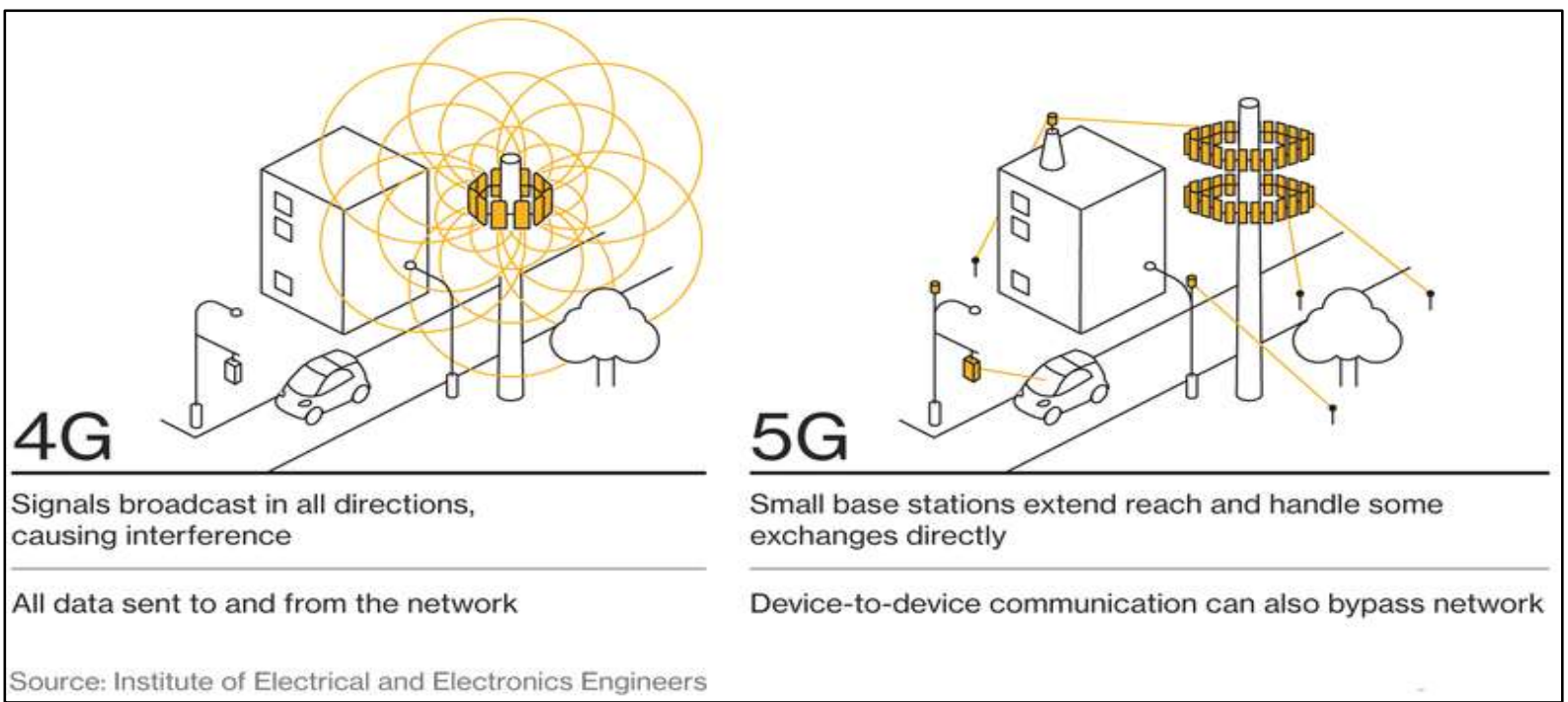

Fig. (1): Comparison between 4G network with $5 \mathrm{G}$ where the capability of $5 \mathrm{G}$ network to bypass and communicate between devices is illustrated (King \& Moritz, 2019).

\section{Conclusion}

The biggest challenge in oil palm industry in Malaysia is to combine IoT and the advanced $5 \mathrm{G}$ network for pragmatic applications. The merging of the mentioned technologies can allow for potential development in managing the oil palm operations in terms of labour, productivity in the field and monitoring yield. The 5G technology in this industry will embark the plantations to move towards smartphone-based environments which will enable control and automation to be made easily accessible.

\section{Conflicts of interest}

The authors declare that they have no conflict of interests.

\section{Acknowledgements}

\section{References}

Abd Rahim, Sh., Khalid M. R., \& Deraman M. S.
(2011). Innovation and technologies for oil palm mechanization. Further Advances in Oil Reserach (2000-2010), Chp 17, 570-597. https://openlibrary.org/works/OL16472418W/Furth er_advances_in_oil_palm_research_2000-2010

Abdullah, R., Ismail, A., Khomeini, A., \& Rahman, A. (2011). Labour requirements in the malaysian oil palm industry in 2010. Oil Palm Industry Economic Journal, 11 ,

$1-12$. http://palmoilis.mpob.gov.my/publications/OPIEJ/o piejv11n2-ramli.pdf

Adiono, T., Dawani, F., Rifai, A., Fauda, S., \& Puwanda, I. G. (2018). Functionality test of communication systems based on LoRa technology in oil palm plantations area. Proceeding-2018. International Conference on ICT for Rural Development: Rural Development through ICT: Concept, Design, and Implication, IC-ICTRuDEv, 18-22.

https://doi.org/10.1109/ICICTR.2018.8706854

Ahmad, S. M., Azman, I., Nordin, A. Z. A., Salleh, K. M., \& Balu, N. (2017). Labour Productivity of harvesters by country of origin: A case study in peninsular Malaysia. Oil Palm Industry Economic Journal, 17 , 1-7. 196 


\section{Shashikant et al. / Basrah J. Agric. Sci., 34(Special Issue 1): 190-198, 2021}

http://palmoilis.mpob.gov.my/publications/OPIEJ/o piejv17n2-mashani.pdf

Aini, I. N., Aimrun, W., Amin, M. S. M., Ezrin, M. H., \& Shafri, H. Z. (2014). Auto guided oil palm planter by using multi-gnss. IOP Conference Series: Earth and Environmental Science, 20, 012013.

https://iopscience.iop.org/article/10.1088/1755$1315 / 20 / 1 / 012013$

Antonio, M, H., Hendy, F., Suhandri, E., Realini, M., Reguzzoni, M., \& De Lacy, C. (2016). GoGPS: OpenSourceMATLABSoftware. (August 26, 2020). https://dl.acm.org/doi/abs/10.1007/s10291-0150469-x

Bohlsen, M. (2018). A look at the $5 \mathrm{~g}$ opportunity. (September 6, 2018). https://seekingalpha.com/article/4204568-look-5gopportunity

Chyan, T. J. (2018). Design of an audio-based machine learning algorithm to detect oil palm fresh fruit bunches harvesting. M. Sc. Thesis. Universiti Tunku Abdul Rahman, 40pp. http://eprints.utar.edu.my/2924/

Edge M. (2020). Malaysia to Champion 5G in SoutheastAsia,MCMC (January 20, 2020). https://www.theedgemarkets.com/article/malaysiachampion-5g-southeast-asia-mcmc

ELE Times Bureau (2019). 5G vs LoRA: How Narrowband Technologies Are the Right Alternative to $5 \mathrm{G} \quad$ (February 12, 2019). https://www.eletimes.com/5g-vs-lora-hownarrowband-technologies-are-the-right-alternativeto-5g

Ismail, A. (2013). The effect of labour shortage in the supply and demand of palm oil in Malaysia. Oil Palm Industry Economic Journal, 13, 1526.

http://palmoilis.mpob.gov.my/publications/OPIEJ/o piejv13n2-azman.pdf

Jelani, A. R., Hitam, A., Jamak, J., Noor, M., Gono, Y., \& Ariffin, O. (2008a) Cantas - A tool for the efficient harvesting of oil palm fresh fruit bunches. Journal of Oil Palm Research, 20, 548-558. http://jopr.mpob.gov.my/cantas-a-tool-for-theefficient-harvesting-of-oil-palm-fresh-fruitbunches/

Jelani, A. R., Hitam, A., Jamak, J., Mohamed, A., Gono, Y., Ismail, F. \&, Nor. M. M. (2008b). Motorized
Chisel (Ckat) for Short Palm Harvesting. $M P O B$ Information Series (TOT-434) (MPOB TT No.409), 2-4. http://palmoilis.mpob.gov.my/TOTV3/tt-no409-motorized-chisel-ckattm-for-short-palmharvesting/

Jelani, A. R.; Shuib, A. R. (2014). Motorized cutting tool. International Patent No. WO201477672A1, 120.

https://patents.google.com/patent/WO2014077672 $\mathrm{A} 1 / \mathrm{pt}$

Jelani, A. R., Azaman, M. I. H. \& Ahmad, M. R. (2019). "The effect of vibration isolator on the magnitude of Hand-Arm Vibration (HAV) of the oil palm motorised cutter (CANTAS). Journal of Oil Palm Research 31, 86-94. https://doi.org/10.21894/jopr.2018.0062

Kalantar, B., M., Idrees, M. O., Mansoor, S., \& Abdul Halin, A. (2017). Smart counting, oil palm tree inventory with UAV. Coordinates by Spring Productions. XIII. 17-20. https://mycoordinates.org/smart-counting-oilpalm-tree-inventory-with-uav/

Kattenborn, T., Sperlich, M., Bataua, K., \& Koch, B. (2014). Automatic single palm tree detection in plantations using uav-based photogrammetric point clouds. International Archives of the Photogrammetry, Remote Sensing and Spatial Information Sciences - ISPRS Archives 40, 139144. https://doi.org/10.5194/isprsarchives-XL-3139-2014

King, I., \& Moritz, S. (2019). Why 5g phones are new focus of freakouts about huawei: Quick take. February 14,2019 https://www.bloombergquint.com/business/why5g-phones-are-new-focus-of-freakouts-abouthuawei-quicktake

Malay, M. (2020). MCMC explains why $5 \mathrm{~g}$ is important for Malaysia's economy. https://www.mcmc.gov.my/ms/media/pressclippings/mcmc-explains-why-5g-is-important-formalaysia\%E2\%80\%99s-e

Malaysian Bussiness Online (2017). A better hope for malaysia's palm oil industry. Malaysian Business Online (August 25, 2020). https://www.malaysianbusiness.com/index.php/mb-features/item/244-abetter-hope-for-malaysia-s-palm-oil-industry

Malaysian, Communications and Multimedia Commission (2019). Final Report on Allocation of 


\section{Shashikant et al. / Basrah J. Agric. Sci., 34(Special Issue 1): 190-198, 2021}

Spectrum Bands for Mobile Broadband Service in Malaysia. (January 29, 2020). https://www.mcmc.gov.my/en/media/pressreleases/final-report-on-allocation-of-spectrumbands-for-m

MIMOS BERHARD (2015). Intelligent Plantation Management. 8pp. http://www.mimos.my/wpcontent/uploads/2015/11/Plantation.pdf

Morgan, H. (2019). How 5G Plays Important Role in Internet of Things? Geospatial world https://www.geospatialworld.net/blogs/how-5gplays-important-role-in-internet-of-things/

My Convergence. (2009). Bridging Communities. Malaysian Communications and Multimedia Commission, $\quad 3(2), \quad 68 p p$. https://www.mcmc.gov.my/skmmgovmy/media/Ge neral/pdf/MyCon05_all.pdf

National Economic Advisory Council (2010). New Economic Model. For Malysia (March 30, 2010). https://www.pmo.gov.my/dokumenattached/NEM_ Report_I.pdf

New Straits Times (2018). Innovation: Drones Home in on Plantations. (March 26, 2018). https://www.nst.com.my/lifestyle/bots/2018/03/349 373/innovation-drones-home-plantations

Shamshiri, R. R., Hameed, I. A., Balasundram, S. K., Ahmad, D., Weltzien, C., \& Yamin, M. (2019). Fundamental research on unmanned aerial vehicles to support precision agriculture in oil palm plantations. In Zhou, J., \& Zhang, B. (Editors). Agricultural Robots- Fundamentals and Applications. IntechOpen. https://doi.org/10.5772/intechopen.80936

Realini, E., Yoshida, D., Reguzzoni, M., \& Raghavan,
V. (2012). Enhanced satellite positioning as a web service with gogps open source software. Applied Geomatics, $\quad 4$ 135-142. https://doi.org/10.1007/s12518-012-0081-5

Realini, E., Caldera, S., Pertusini, L., \& Sampietro, D. (2017). Precise GNSS positioning using smart devices. Sensors, $17(10), \quad 2434$. https://doi.org/10.3390/s17102434

Rudiyanto, R., Minasny, B., Setiawan, B. I., Saptoma, S. K., \& Mc-Bratney, A. B. (2018). Open digital mapping as a cost-effective method for mapping peat thickness and assessing the carbon stock of tropical peatlands. Geoderma, 313, 25-40. https://doi.org/10.1016/j.geoderma.2017.10.018

Shuib, A. R., Jelani, A. R., Jahis, S., Deraman, M. S., Khalid, M. R., Hitam, A., Basiron, Y., \& Wahid, M. B., (2004). Development of A machine for harvesting tall palms. MPOB TT No. 217. 1-2. http://palmoilis.mpob.gov.my/publications/TOT/T T-217.pdf

Shuib, A. R. Kamaruddin, N., Harun, M. H., Omar, W., Abu Seman, I., Ali, S. R. A., Mohamed, M. T., \& Mohamed, A. (2008). Otowey: An infield FFB transporter with electronic weighing system. Transfer of Technology (TOT). MPOB Information Series

(TOT-433). http://palmoilis.mpob.gov.my/publications/TOT/T T-408.pdf

The Edge Markets (2018). Mysay: Business as usual not an option anymore for oil palm industry. https://www.theedgemarkets.com/article/mysaybusiness-usual-not-option-anymore-oil-palmindustry 